\title{
The evolution of EU-South Africa relations: What influence on Africa?
}

\author{
Lorenzo Fioramonti* and John Kotsopoulos \\ Centre for the Study of Governance Innovation, University of Pretoria, South Africa \\ *Corresponding author. Email: lorenzo.fioramonti@gmail.com
}

\begin{abstract}
South Africa and the European Union (EU) have a longstanding relationship. Their interaction has evolved through various phases, characterised simultaneously by ambitious partnerships coupled with a degree of wariness. As international dynamics change and Africa becomes an increasingly crucial player in global politics, the relationship between the EU and South Africa exerts a host of influences on how Africa and Europe relate to each other. This article discusses the evolution of EU-South Africa relations and highlights direct and indirect influences that this relationship has on the inter-regional partnership between Africa and Europe.
\end{abstract}

Keywords: European Union; South Africa; Africa; African Union; interregionalism

\section{Introduction}

South Africa's post-apartheid foreign policy has taken numerous twists and turns as it finds its place in Africa and beyond. The country's foreign policy has often been categorised by three phases, corresponding to the tenure of its three post-apartheid presidents, Nelson Mandela, Thabo Mbeki and Jacob Zuma. Yet whether it is Mandela's moral power, Mbeki's pan-Africanism or Zuma's pragmatism, South Africa's regional influence remains evident, although the execution of this influence is open to contestation. Unsurprisingly, interpretations of South African foreign policy tend to highlight its inconsistencies both towards the rest of Africa and further afield, including the global North. ${ }^{1}$ The country presents itself, or is viewed by commentators, as engaged in a balancing act of multilateralism and unilateralism, pan-Africanism and self-interest, a 'pivotal state' and a 'hegemon', ${ }^{2}$ a sub-imperial force, ${ }^{3}$ a SouthSouth leader or a cosy partner to the global North. ${ }^{4}$

Most of these dynamics are also evident in the evolution of the relationship between South Africa and the European Union (EU), as well as with respect to the influence of South Africa in EU-Africa inter-regional relations. For decades, the trade and aid conventions with the Africa, Caribbean and Pacific Group of States (ACP) ensured the prominence of the EU on the continent. This position was further entrenched by the deep, yet often problematic, relationships that many former European colonial powers retained in Africa. Circumstances, however, have changed in the past decade. European countries and the EU as a whole are still important political and economic partners of Africa, but their comparative advantage in the continent has been eroded by the growing influence of emerging economies. China, 
India and Brazil are expected to surpass the UK, France, Germany and Italy in economic output by $2020 .{ }^{5}$ While adopting a comprehensive partnership with the EU and confirming its regional trade links with Europe, the African continent as a whole has become more assertive of its prerogatives, expanding relations to other parts of the world and seeking to take control of 'African solutions to African problems'. Studies of public perceptions of Europe in Africa also confirm this downward trend. ${ }^{6}$

From the EU's perspective, South Africa holds a crucial position in terms of bilateral relations and as a leader of regional governance in Africa. It is a prominent member of North-South clubs like the G20 and the G7 + 5, where key EU member states (as well as the European Commission) are represented. It is one of the EU's 10 strategic partners globally, covering a wide array of cooperation areas, from energy to trade and migration. Moreover, as a leading voice in African regionalism, South Africa is seen by the EU as a critical entry point in its inter-regional relationship with the continent. ${ }^{7}$ In some ways, South Africa plays the role of 'bridge' between the North and South: a regional leader with a global status and a potential ally in the quest for increasingly norms-based international governance structures. ${ }^{8}$

This article focuses first on the evolution of the relationship between South Africa and the EU, including current tensions and ambiguities. The second section explores South Africa's changing foreign policy prerogatives. The latter section synthesises the earlier sections, exploring South African foreign policy and its influence (or lack thereof) on EU-Africa relations, examining both direct and indirect channels. Such a triangular investigation (South Africa-EU-Africa) is essential to understand the complex dynamics involved in inter-regional cooperation between Europe and Africa, while also connecting this cooperation to the fast-changing global balances of power. The rise of the developing world, and linkages within it, is a major contributing factor not only in trade terms but also in terms of perceptions of who is relevant and who is less so. At the same time, although the EU's 'structural power' may be challenged by competing actors, ${ }^{9}$ it remains an important partner to both South Africa and the larger continent in areas such as trade, aid, peace and security.

The article reviews the key literature in the areas of South Africa as a foreign policy actor and EU-South Africa relations. To make some of the original linkages with South Africa-EU-Africa relations, analysis relies partially on results from a focus group conducted with EU officials in South Africa in September 2014, in addition to further interviews carried out in the first half of 2015.

\section{The evolution of EU-South Africa relations}

This section looks at the political and trade frameworks through which the EU and South Africa interact. The purpose is to review the evolution of the bilateral relationship and shed light on the current dynamic between the two actors.

Almost four centuries of history link South Africa to European countries. Initially it was colonialism, with both Dutch and then British domination. During this period, South Africa fell within the overall approach of 'divide and rule' carried out by European colonisers, supporting the British expansion in the rest of the continent and aiding Western powers in both World Wars. During the apartheid era, European countries were initially silent about the institutionalised form of discrimination operated by the white-controlled government. It was not until the 1970s that European governments and the then European Economic Community began to join the UNled international campaign against apartheid. It was however only in the mid-1980s 
that Europe's member states became vocal against the South African regime, adopting a wide range of sanctions and a special programme to support the victims of apartheid. ${ }^{10}$ With the establishment of democratic rule in South Africa in 1994, the relationship between the EU and the new government began to normalise, with a strong focus on trade partnerships, development cooperation and democracy promotion both in the country and throughout Africa. This normalisation, however, occurred at a time in which the globalisation of markets brought new actors into the picture, especially the emerging powers of the global South.

Up until the early 2000s, the EU was still South Africa's main trading partner. Even currently, the EU is just behind China in terms of import and export of goods, ${ }^{11}$ while South Africa is the EU's main trading partner in Africa. ${ }^{12}$ South Africa also represents a unique partner for the EU beyond trade, since it is perceived 'as a strategic partner in African and global affairs, particularly because of its leadership role in the southern African region, in Africa in general, and in the rest of the developing world.' ${ }^{\text {13 }}$

Moreover, South Africa's 'aggregate capabilities in terms of economic, diplomatic and military capacities, in relation to other African nations' automatically define it 'as a regional power or hegemon', not only in the eyes of the EU but for the rest of the world too. ${ }^{14}$ As a middle income country - notwithstanding the persistent and profound challenge of domestic inequality - it also represents the closest manifestation of a 'developed' country in Africa. Ideationally as well, South Africa's foreign policy agenda has regularly chimed with the normative values that the EU also touts. This includes the linking of development to the respect for human rights, democracy, international law, peace and security. In addition, South African promotion of regional and pan-African integration has provided points of convergence with the interests of the EU.

The EU-South Africa relationship is a comprehensive one, structured along both trade and political lines. The Trade, Development and Cooperation Agreement (TDCA) signed in 1999 accounts for $90 \%$ of trade between the two sides, governing the access of goods and services to the respective markets. At the political level, relations between South Africa and the EU are guided by a bilateral strategic partnership (the only in Africa), which identifies the need for continent-wide cooperation and singles out South Africa's contribution to regional integration in support of the key regional cooperation and integration processes, namely the African Union (AU) and the New Partnership for Africa's Development (NEPAD), as well as the Southern African Development Community (SADC) and the Southern African Customs Union (SACU). ${ }^{15}$

Both sides also have their own regional strategies delineating policies which concern each other. The 2011 White Paper of the Department of International Relations and Cooperation (DIRCO) explicitly reaffirms the importance of relations with the EU, not only in terms of potential South African market opportunities, but also as a partner to help tackle continental challenges such as peace and security. ${ }^{16}$ Regular summits have also been held between the two actors on a near yearly basis since 2008, with the joint communique delivered at the end of each summit being used as a general agenda for cooperation.

While the comprehensiveness of the relationship is not in question, its prominence has shifted discernibly in the $21^{\text {st }}$ century. In 1999, when the TDCA was being negotiated, it was the EU that came to the table from a position of strength with South Africa in need of European market access, particularly for agricultural goods. ${ }^{17}$ It is 
unlikely that such a dynamic would be the case today, given South Africa's burgeoning South-South cooperation. In fact the TDCA itself will soon be subsumed by an economic partnership agreement (EPA) with some of the members of SADC, including South Africa. ${ }^{18}$ Moreover the aforementioned strategic partnership and Joint Country Strategy Paper was due to be updated in 2014, ${ }^{19}$ but at the time of writing continues to be delayed. This lack of urgency could be interpreted as reflecting the diminishing status of the relationship.

There is also a lingering wariness that affects relations between the two sides. The EU's power to 'define the stature of its partners, decide what they deserve in the relationship and define the nature of new relations ${ }^{20}$ has caused resentment. This has been evident in annual EU-South Africa ministerial dialogues and specifically with respect to EU efforts to change the terms of the relationship, with a diminishment of aid and increase in trade, based on its deeming South Africa a middle income country. ${ }^{21}$ An EU official interviewed in Pretoria interpreted the tension as a South African assumption that the EU had a hidden agenda. ${ }^{22}$ The same official felt that South Africa took a defensive posture in dialogue with the EU, reticent about engaging in conversation on controversial issues for fear of being 'lectured'. ${ }^{23}$ An example provided of this defensive posture was the EU's attempt to discuss the 2015 xenophobic attacks in South Africa which was countered immediately by a South African wish to discuss the death of migrants in the Mediterranean.

In terms of the governance structure driving South Africa's foreign policy and by extension affecting EU-South Africa relations, there has been a growing influence exercised by the Office of the President at the expense of DIRCO, especially under Jacob Zuma. Long-term foreign policy objectives seem to have become less of a priority, as indicated by the lack of an international relations adviser in the president's office, which has opened the way to a rather haphazard approach to international affairs. The EU section of DIRCO, for example, has decreased in size as resources have shifted elsewhere. Other elements of South Africa's multifarious foreign policy place it in divergence with EU policy. South Africa sees itself as a member of the global South and thus as a champion of the South's interests. While this does not imply that its policies are designed in opposition to the North, it does mean that its agenda is driven by a 'collective search for global redistributive justice'. ${ }^{24}$ The white paper reflects this, explicitly stating South Africa's responsibility to push back against EU policies with 'detrimental effects' such as the Common Agricultural Policy. ${ }^{25}$ As Olivier and Fioramonti have shown in their pivotal research about perceptions of the EU in South Africa, the former is increasingly viewed as a less relevant partner. ${ }^{26}$ The white paper, for instance, places Europe below Asia and the Middle East in South Africa's 'Global Positioning'. This perception shift also symbolically manifested itself at the funeral of Nelson Mandela in December 2013. Despite a number of heads of state from Africa and the global South being invited to speak at the commemoration ceremony, no European shared the stage - perhaps a reminder of Europe's incremental fall from prominence. In April 2014, Jacob Zuma's choice not to attend the EU-Africa Summit was not necessarily a sign of animosity between the two parties but a further indication that the relationship with the EU has become increasingly marginal in the list of political priorities of the current South African leadership. 


\section{South Africa as a global and regional leader}

This section explores South Africa's role in global and regional relations highlighting the dualist tension (ie, at once a developed and developing country) in its foreign policy. The purpose is to shed light on areas of global and regional influence which, as we shall see in the final section, can affect EU-Africa relations.

The international and multilateral orientation of South Africa is tied to several factors, including its economic power and relative capacity, as well as an historical predilection for internationalism. ${ }^{27}$ These qualities have provided the impetus for South Africa to seek significant influence beyond its borders. Manifestations of this influence include its unique status as sub-Saharan Africa's only representative within prominent international bodies such as the G20, BRICS and IBSA. Complimenting South Africa's material power is its ideational influence, rooted in the country's peaceful deliverance from its racially oppressive past. Armed with one of the world's most progressive constitutions, the legacy of Nelson Mandela and near unparalleled economic clout in the continent, South Africa's status as a regional power is evident. ${ }^{28}$

At the end of apartheid, it was the universally feted stature of Nelson Mandela that provided South Africa with a unique moment. Mandela chose to capitalise on it by situating South Africa as a "model global citizen"29 and attempting to exercise 'moral suasion' ${ }^{30}$ on a continent still reeling from the economic and political upheavals of the 1980s and a deep institutional malaise. Mandela sought to encourage African partners to address human rights, respect for international law, peace and disarmament and universality. ${ }^{31}$ Mandela (and his successor Thabo Mbeki) also made a direct connection between the lack of human rights and democracy and Africa's development - a linkage still on the fringes at the time. ${ }^{32}$

Mandela's administration also received plenty of encouragement from the global North, where South Africa was seen as a 'home grown' power capable of providing needed leadership on the continent. ${ }^{33}$ Yet continental leadership did not necessarily bear immediate fruit, as exemplified by Mandela's failure - despite personal pleas to halt the execution of celebrated Nigerian activist Ken Saro-Wiwa by the Abacha regime. Other incidents, such as Mandela's open criticism of undemocratic African regimes and the 1999 SADC invasion of Lesotho, ultimately antagonised many African governments. ${ }^{34}$ As indicated by some analysts, "the ability of the South African government to act decisively in the name of African interests is more accepted in global settings like the G8 or WTO than is always the case within Africa'. ${ }^{35}$ This was also compounded by South Africa's still nascent and at times awkward presence as a political and military actor in Africa, especially against the background of the ingrained cultural hostility by African nations towards the country during the apartheid era. Indeed, its power (both political and economic) became increasingly contested in the rest of Africa, with 'big brother' resentment surfacing throughout the continent: '[South Africa] was to learn that while power may stimulate respect, it seldom fosters love'. ${ }^{36}$

Nonetheless, grand ideas about Africa's regional development continued to emanate from post-apartheid South Africa. It was during the presidency of Thabo Mbeki that systematic efforts began to enhance South Africa's role on the continent in a variety of areas, including regional cooperation and integration, where South Africa became 'a leader in the reconstruction of Africa's institutional architecture'. ${ }^{37}$ Mbeki memorably declared himself 'an African' in a highly symbolic 1996 speech 
which highlighted the wish for South Africa - so long a pariah - to take its place back within the continental community. ${ }^{38}$

Pretoria subsequently played a pivotal role in the creation of the AU to replace the moribund Organisation of Africa Unity as well as establishing a new vision for the continent's development, as enshrined in the constitutive act of NEPAD. The Mbeki administration provided political (and possibly moral) leadership too, encouraging African governments to modify their domestic policies in order to 'realise the higher goals of sub-regional and continental integration'. ${ }^{39}$ This was not of course a straightforward process. Indeed, 'some of Africa's "big men" were not happy that the marks of South Africa's liberal internationalism were all over the new body'. ${ }^{40}$ Some were also suspicious of the AU's close working ties with the North - a factor widely attributed to continued influence of Pretoria's white old-regime forces. ${ }^{41}$

Tied with pan-African institutional reform was capacity building, particularly in the area of peace and security. Here too Mbeki, who served as the AU's first chair, oversaw the design of the foundations of the organisation's peace and security mechanisms, later known as the African Peace and Security Architecture (APSA). ${ }^{42}$ These institutions, incidentally, would serve as focal points for the EU's relations with Africa, as shall be explored below.

Whereas the Mandela approach of naming and shaming was often explicit, Mbeki embraced 'quiet diplomacy'. Some argued this was a reflection of South Africa's weakness and lack of moral suasion. ${ }^{43}$ Yet the Mbeki approach chimed better with the general ethos of international relations on the continent and helped bind South Africa to the rest of Africa rather than further alienating it, even if that meant exposure to external criticism for relative quiet on controversial issues like the crisis in Zimbabwe. ${ }^{44}$

Jacob Zuma has kept this approach despite criticism that his quiet diplomacy is less about Mbeki's structured dialogue and more a simply reactive process. ${ }^{45}$ Although his administration initially signalled that it would change course and make foreign policy about the 'advancement of domestic priorities', ${ }^{46}$ his government has retained much of the comprehensive approach of the Mbeki administration, minus some of the loftier rhetoric. For instance, talk of regional cooperation in the form of the 'African Renaissance' has given way to the more pragmatic 'African Agenda'. One gradual but obvious change in South African foreign policy towards Africa has been its increasing discretion with respect to countries with poor democratic governance records, as epitomised by the decision not to apprehend Sudanese President Al-Bashir when on South African soil in 2015 despite a warrant from the International Criminal Court (of which South Africa is a signatory) and a formal request by the national judiciary. ${ }^{47}$

Interpretations of South Africa's foreign policy and its approach to African regionalism differ. The aforementioned internationalist and multilateral orientation towards the continent has also been contrasted with a more inward and domestic-driven agenda, couched in the propagation of South African economic interests in particular.

This dualism has even been reflected in the differing interests of South Africa's government institutions, particularly between DIRCO and the Department of Trade and Industry (DTI). In the case of the former, continental initiatives were to be situated within the framework of the AU and NEPAD, reinforcing South Africa's commitment to pan-African partnerships. In contrast, DTI was tasked with creating an 'enabling market environment' in Africa for the private companies hailing from the 'Rainbow Nation', with state-guaranteed risk insurance to assist large South African exportoriented businesses. ${ }^{48}$ For some, this is a clear indication that South Africa acts 
more as a sub-imperial power interested in pursuing its own economic expansion into the African continent than as a truly Pan-African leader. ${ }^{49}$

Likewise, South Africa's prominent contribution to regional integration has been criticised by some as helping to create institutions which mirror its values - but not necessarily those of other countries on the continent. NEPAD and its African Peer Review Mechanism, a governance review system looking at both political and economic credentials of member states, have garnered particular criticism as extensions of a neoliberal agenda. ${ }^{50}$ Some of these accusations have also targeted South Africa's ruling party, the African National Congress, which has been accused of side-lining Pan-Africanist sentiments to the advantage of domestic economic forces keen to expand to the rest of the continent. ${ }^{51}$

South Africa also riled many countries in Africa with its strong push to replace AU Commission Chairman Jean Ping with the former South African Foreign Minister Nkosazana Dlamini Zuma. The tactics and manoeuvring involved in the succession sparked controversy and fears of a new South African push to dominate the continental agenda. ${ }^{52}$

\section{What influence on EU-Africa relations?}

As demonstrated in the previous sections, South Africa exerts a significant, although sometimes contested, influence on the African continent. Its contribution to the multilateral relationship between the EU and Africa is an extension of this influence and can take direct and indirect forms. For instance, direct influence comes through South Africa's role in the intercontinental partnership, the Joint Africa-EU Strategy (JAES), as well as its leading contribution to the Africa-EU high level meetings and the inter-regional dialogue between the EU and the various subregional organisations, notably SADC. South Africa has also been prominent in economic partnership agreement negotiations and Africa's resistance to them. South Africa also affects the EUAfrica interaction in a variety of indirect ways, particularly through its pivotal contribution to the AU and NEPAD, including regional conflict management, but also through its interaction with the rest of the world, which in turn affects how South Africa behaves internationally. As discussed, South Africa is not only a regional leader and a privileged partner of the EU, but it is also a dynamic player in many global governance fora, from the G20 to the BRICS, with aspirations to represent the global South in its dialectic relationship with the global North, especially in the field of global trade and climate change negotiations.

Figure 1 represents the complexity of these different forms of influence and how they intervene in the intercontinental relationship between the EU and Africa. As the figure shows, most indirect forms of influence have contributed to triggering tensions in EU-Africa relations.

\section{Direct influence}

The JAES is the 2007 landmark political framework agreement that guides relations between the EU and the African Union (or 'Africa', since it also includes non-AU member Morocco). South Africa played a key role in the negotiation and implementation of the JAES. For example, it was represented in six of the eight thematic 'partnerships' which served as implementing tools of the JAES until 2014 - more than any other country. ${ }^{53}$ Similarly, South Africa was the only Sub-Saharan African country to 


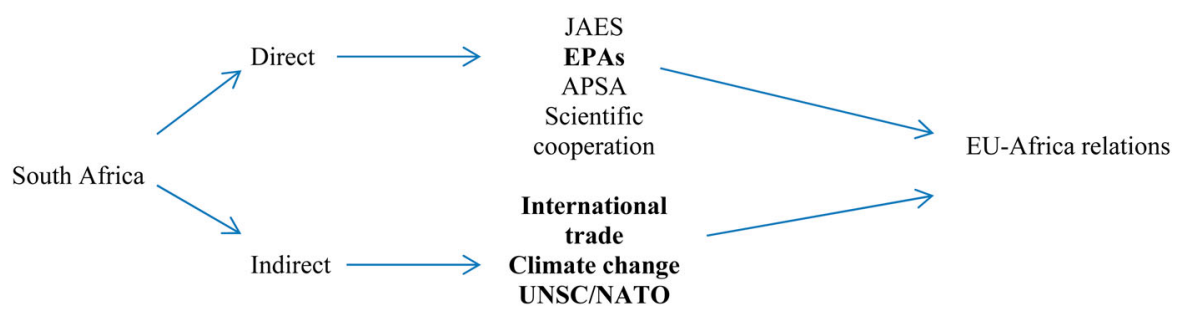

Figure 1. Patterns of South Africa's influence on EU-Africa relations.

Source: Authors' own conception.

Note: Areas of influence that have contributed to generating tensions in EU-Africa relations are highlighted in bold.

co-chair (with an EU member state) a specific area of the partnership, the Trade, Regional Integration and Infrastructure Partnership. ${ }^{54}$

South Africa also directly influences the broader EU-Africa relationship through its own strategic partnership with the EU. 'South Africa will continue to leverage its strategic partnerships with the EU and its major member states to ... support the AU's peace and security initiatives'. ${ }^{55}$ The regularised system of dialogue between South Africa and the EU, manifested in annual ministerial dialogues but also more frequently by diplomats in Pretoria and Brussels, has permitted both sides to put regional issues on the table. Peace and security, for example, is a prominent area of discussion. A recent ministerial dialogue committed both sides to seek joint leadership opportunities in order to address the prevention and resolution of conflicts such as those in Somalia and the Sahel. ${ }^{56}$ The EU has also sought to bolster South Africa's push for a more comprehensive approach to security on the continent by allocating money from the Africa Peace Facility for APSA. ${ }^{57}$ Likewise the EU has provided capacity-building support for the African Standby Force, an initiative driven by President Zuma.

South Africa also played a directly influential role with respect to the economic partnership agreement negotiations which exploded into life in 2007 with the impending expiry of the special trade provisions granted to ACP countries. ${ }^{58}$ The new framework related to the new multilateral trade framework sponsored by the World Trade Organization (WTO). While the Lomé conventions and subsequent Cotonou Agreement had historically offered the ACP a comparative advantage (ie, preferential market access) vis-à-vis other (also developing) countries, this type of 'privileged' relationship would no longer be tolerated under the new reciprocity philosophy endorsed at the global level. Since non-discrimination is a fundamental tenet of multilateral trade, the EU was faced with only two options: offer the same preferences in a non-discriminatory way to all developing countries or negotiate a different trade agreement with the ACP countries. The EU opted for the latter. In the specific case of Southern Africa, the impact of the EPA on regional integration was further compounded by the existence of the TDCA with South Africa, which had historically complicated internal relations within both SACU and the SADC. ${ }^{59}$ According to Rob Davies, the South African Minister of Trade and Industry, the European Commission adopted a 'threatening' strategy characterised by a 'take-it-or-leave-it' approach: 'This led to a situation where a country that was unwilling to sign on did so under huge duress and with little enthusiasm'. ${ }^{60}$ 
The South African contrarian stance on the EPA negotiations motivated other African countries to reject the proposals put forward by EU institutions in 2007. Having an existing trade agreement with the EU, South Africa had no incentive to support an extension of this arrangement to the region. Supported by Namibia, it showed hostility towards the EPA. This led to Botswana, Lesotho, Swaziland and Mozambique breaking ranks and signing an interim arrangement with the EU, as they feared losing market access for their exports to Europe. ${ }^{61}$ These events followed a prior division within the region, when other members such as Mauritius, Malawi, Zambia and Zimbabwe decided to quit SADC's EPA and join the East Africa EPA grouping, at a time when SADC was in the process of establishing a trade protocol to liberalise all internal trade.

According to Kornegay and Olivier, the EPAs posited the threat of 'an economic recolonisation' of Africa through a new 'divide and rule' rendition of 'an already complicated regional integration terrain'. ${ }^{62}$ For others, the most enduring legacy of the EPA process is likely to be the potentially fatal blow it has dealt to feeble regional economic integration efforts in sub-Saharan Africa. ${ }^{63}$ Also the AU pointed out the serious risk that the EPAs might undermine the lengthy process of regional cohesion and cooperation, at a time when Africa was 'taking significant measures to enhance regional integration and address the question of rationalisation of the RECs' ${ }^{64}$ President Jacob Zuma weighed in on this issue as well, maintaining that the EPA negotiation had called into question the future of local customs unions. ${ }^{65}$

Away from trade negotiations, South Africa and the EU have used their longstanding cooperation in the field of science and technology to cooperate on some continent-wide issues. Complimenting the AU's targeting of radio astronomy as a priority area for EU-Africa cooperation, South Africa has provided one of two global locations (the other is in Australia) for the world's largest radio telescope - the Square Kilometre Array Project. It is also playing a facilitating role for the African-European Radio Astronomy Platform, which will fund partnerships in the field of astronomy with the purpose of socioeconomic growth. ${ }^{66}$ Initiatives in science that contribute to innovation and poverty alleviation have been identified as target areas by the Zuma administration. ${ }^{67}$

In climate change negotiations, the 'pull effect' exercised by South Africa's allegiance to the global South has had a significant effect on the EU's capacity to influence African governments' decisions. At the UN Climate Change Conference (COP17) in 2009, the proposal on emission reductions tabled by the European Commission was rejected by a coalition of countries led by South Africa, China, India and Brazil, exacerbating a rift between European countries and developing nations, especially in Africa. Subsequently, the influence of the EU on a post-Kyoto framework on climate change has been massively reduced, with a more proactive role taken by South Africa (which hosted international talks in 2011) and other emerging powers of the global South, namely China and India. ${ }^{68}$ African governments have by and large aligned themselves behind South Africa's stance, with Africa's regional organisations particularly silent on the possibility of a continental framework on climate change mitigation and adaptation.

\section{Indirect influence}

South Africa's indirect influence in EU-Africa relations comes in various guises. Its opinion, for one, has weight. At a focus group meeting conducted with EU diplomats 
in Pretoria, it was noted that the views of the president's office and DIRCO about issues and events on the continent and beyond were of high diplomatic value. ${ }^{69}$ At the same time, the focus group and subsequent interviews with EU officials revealed a frustration with the perceived reactive and inconsistent foreign policy of the Zuma presidency. One noted that as a G20 country South Africa was in a position to lead, but chose not to, paralysed by its dual role as a 'cutting edge' yet also traditional society. ${ }^{70}$ An example of this indecision has been South Africa's vacillation about a UN resolution on Lesbian, Gay, Bisexual and Transgender (LGBT) rights, which it sponsored and which was acclaimed by the EU as an important step towards fighting discrimination. After a notable backlash in other African countries such as Uganda and Nigeria, South Africa seemed to back away from the issue entirely. Ultimately South Africa did vote in favour of the LGBT rights resolution at the Human Rights Council in September 2014 - the only Human Rights Council member from Africa to vote in favour. The country was, however, accused of watering down the document. ${ }^{71}$ One EU diplomat suggested that South Africa 'wouldn't dare' challenge continental orthodoxy on LGBT matters ${ }^{72}$ while other pundits deemed the whole fracas symptomatic of the country's failure to provide leadership on the continent. ${ }^{73}$

Besides the 2015 Bashir incident discussed earlier, South Africa's discernible turn to the global South has had indirect consequences on the EU-Africa relationship. For example, South Africa's voting pattern during its two recent stints on the UN Security Council (2007-2008 and 2011-2012) reveals a tendency to side with Chinese, Russian and other 'like-minded' group interests. ${ }^{74}$ South Africa chose to buck liberal democratic voting tendencies at the UN by taking technical positions against sanctions on Iran, Myanmar and Zimbabwe, as well as avoiding condemnation of rape as a political and military weapon. ${ }^{75}$ In its own backyard, South Africa has been accused of using the weaker diplomatic mechanisms of SADC as a means through which to avoid more explicit condemnation of regional problems, such as electoral irregularities in Zimbabwe. ${ }^{76}$ For better or for worse, these examples of an independent South Africa show that it is not necessarily a consistent partner with respect to the EU's normative ambitions for its relations with Africa.

Further fanning the flames of EU-South Africa tensions, and by extension issues in EU-Africa relations, has been a serious diplomatic spat with NATO (and hence EU Member States) over the Libyan conflict in 2011. The African Union and President Zuma had argued for a patient and diplomatic approach to Libyan President Muammar Gaddafi and his possible departure from power. Europe and North America, under the umbrella of NATO, ostensibly disregarded African pleas and proceeded with an aerial bombardment which ultimately precipitated the toppling and death of Libya's long-time ruler. The contrast in perceptions of this event remains profound. The North saw it as a necessary act of assistance during the euphoric early 'Arab Spring' phase, as well as the deposition of a notorious dictator. Jacob Zuma and others saw it as an insult, ${ }^{77}$ a failure of the North to heed any of its own rhetoric about 'partnership of equals' or assisting the continent with its pledge to find 'African Solutions for African Problems'. The bombings were also deemed to have unleashed new and unprecedented instability; one consequence has been the wave of migration to Europe through the Mediterranean. Zuma reminded his European counterparts of this in a recent remark: 'The consistent' systematic bombing of Nato forces undermined security and caused the conflict that continues in Libya and the neighbouring countries ... They [Europe] don't want to accept the refugees. They caused it' ${ }^{78}$ The failure of the EU and Africa to better coordinate their responses to the Libyan 
crisis has been deemed 'organised inaction' and reflective of the gulf between Europe and Africa regarding conflict intervention. ${ }^{79}$

To reverse the analysis and think briefly about the EU's influence on South Africa on the continent, an interesting area to examine is regional trade. For example, the terms of the TDCA, which established a free trade arrangement with South Africa at a time when the rest of the region and the continent traded with the EU under the separate framework of the Lomé Conventions (and Cotonou Agreement since 2000) or the 'Everything-But-Arms' scheme reserved for least developed countries, contributed to setting South Africa apart from the rest of Africa on the problematic grounds that the post-apartheid economy should be treated differently from other developing African economies. ${ }^{80}$ The TDCA provoked a profound rift between EU and South African negotiators; the latter would have much preferred South Africa to be incorporated into the existing trade agreement with the rest of Africa, which offered more advantageous asymmetrical access to the EU market and non-reciprocity conditions. The TDCA also generated imbalances within the pre-existing SACU, as tariff-free European goods penetrated other neighbouring countries once entering through South Africa.

\section{Conclusion}

Post-apartheid South Africa's international and regional identity remains in flux, making its foreign policymaking process a dynamic one. Not only have individual heads of state helped shape and re-shape South Africa's orientation and priorities, but a dramatically shifting global landscape has also compelled the country to react. This has been particularly evident with respect to South Africa's growing identification with the emerging economies of the global South.

Amidst these internal and external pressures a type of dualism can be discerned. As both scholars and practitioners have surmised, South Africa is at once a developed and developing country, with all of the concomitant challenges a profound contrast like that implies. Given its uniquely advanced economy in sub-Saharan Africa, South Africa is considered almost by default a regional power or 'pivotal state'. This has also implied a responsibility to act and an expectation to lead beyond its borders, even if such a hegemonic role might be contested by other actors in Africa. To its credit, South Africa has been conscious of its historical baggage and has attempted to tread softly in pan-African affairs, particularly with regard to respecting values that might not be reflected in its own constitution but correspond with the ethos of the bulk of countries on the continent. Still, its role is not a universally accepted one.

The same expectations of South Africa as a global and regional actor apply for its partners beyond Africa. Judging simply by the range of prominent international organisations of which it is the sole sub-Saharan member, it is clear many of Africa's suitors - from the North or the South - look to South Africa first. And despite fluctuating and changing and sometimes contradictory foreign policy, the country has nonetheless managed to broadly straddle North-South and SouthSouth lines. It has maintained a policy of solidarity with the developing world and focused on strengthening political and economic ties with emerging economies such as those of the BRICS, while also retaining traditional trade and political ties with the EU. ${ }^{81}$ As a South African parliamentary committee concluded, this triangular 'North-South-South' approach is steeped in pragmatism, because 'although the country's long-term future lay with the Third World, "there are certain realities we dare not 
ignore", 82 This sentiment was later seconded in the 2011 DIRCO White Paper, which made note of the utility of triangular cooperation with the EU in order to promote its African Agenda. ${ }^{83}$

This study showed that, while the EU retains its importance as a partner for South Africa, the interaction is now fully embedded in the latter's continuing rapprochement with its own continent and its ambitious projection in the global South. Moreover, South Africa's approach can be increasingly defined as part of a realpolitik towards regional and bilateral interests. The implications are that, especially at the political level, the EU-South Africa relationship is characterised by oscillations. In some areas, the interaction is fluid and mutually beneficial (eg, in scientific cooperation and investment), while in others it is in flux, from trade to regional integration to the promotion of 'normative values'. ${ }^{84}$

It is crucial here to make the link to the EU's larger relationship with Africa. It is clear that South Africa enjoys direct and indirect influence on EU-Africa relations which can have a variety of repercussions. This paper has shown that South African resistance, for instance, has led to stumbling blocks at the multilateral level such as in the case of the EPA negotiations. On the other hand, South African expertise and leadership have benefitted the design of the political framework between the EU and Africa - the JAES. The two sides have also worked constructively to enhance ambitious security initiatives driven by the African Union.

Yet assumptions about what South Africa represents on the continent cannot, as we have seen, remain static. The universal frustration of EU diplomats interviewed for this paper is indicative of an inability to pin down an oscillating partner who may or may not share the same broad normative aspirations as the EU for its relationship with the continent. There is a sense that South African foreign policy is more reactive than ever and that leadership opportunities at the continental level are being missed. The example of South Africa's voting behaviour at the UN Security Council is a case in point. Whether this is symptomatic of a permanent trend or a reflection of the predilections of the current president is difficult to ascertain.

Of course South Africa cannot shoulder all of the responsibility for frustrated European diplomats. As shown, the EU continues to elicit wariness by its sometimes heavy-handed approach, particularly to trade. Its way of agenda setting and the means by which it bestows status (such as deeming a country 'middle income') point to a hegemonic approach that can elicit defensiveness. Indeed, in this context, any influence from the outside, especially if couched within an allegedly 'normative' framework, can easily be perceived as an unwelcome interference. Finally, it is useful to remember that Africa is not a monolith.

Approaching the continent via a bilateral strategic partnership with a regional hegemon may ultimately be counterproductive, especially as this preferential treatment may ultimately undermine the credibility of local partners in pursuing genuinely home grown regional cooperation strategies.

Clearly South African foreign policy and EU-South Africa relations are going through a period of adjustment. The revision of priorities has meant that the relationship between the EU and South Africa no longer holds the same undisputed rank as it once did. That said, there is clearly space for South Africa to play an influential role in shaping EU-Africa inter-regional relations. The question remains just how much South Africa wishes to play that role. 


\section{Notes on contributors}

Lorenzo Fioramonti is Professor of Political Economy at the University of Pretoria (South Africa), where he directs the Centre for the Study of Governance Innovation. He is also Senior Fellow at the Centre for Social Investment of the University of Heidelberg and at the Hertie School of Governance (Germany) and Associate Fellow at the United Nations University. Fioramonti is also the first and only Jean Monnet Chair in Africa and also holds the UNESCO-UNU Chair in Regional Integration, Migration and Free Movement of People. His most recent books are How Numbers Rule the World: The Use and Abuse of Statistics in Global Politics (Zed Books 2014) and Gross Domestic Problem: The Politics Behind the World's Most Powerful Number (Zed Books 2013).

John Kotsopoulos is a postdoctoral research fellow at the Centre for the Study of Governance Innovation, University of Pretoria. He holds a $\mathrm{PhD}$ in International Relations (University of Kent, UK) with a focus on asymmetrical negotiations between the European Union and Africa. He was formerly a policy analyst with the European Policy Centre in Brussels and earlier served as a political desk officer at the Department of Foreign Affairs in Ottawa, Canada.

\section{End notes}

1. Nathan L, 'Consistency and inconsistencies in South Africa foreign policy', International Affairs, 81.2, 2005, pp. 361-72.

2. Habib A, 'South Africa's foreign policy: Hegemonic aspirations, neoliberal orientations and global transformation', South African Journal of International Affairs, 16.2, 2009, pp. 143-59. Schoeman M, 'South Africa in Africa: Behemoth, hegemon, partner or "just another kid on the block", in Adebajo A, A Adebayo \& C Landsberg (eds) South Africa in Africa: The Post-Apartheid Era. Scottsville: University of KwaZulu-Natal Press, 2007, pp. 92-104.

3. Bond, P, 'The ANC's "left turn" and South African sub-imperialism', Review of African Political Economy, 31.102, 2004, pp. 599-616.

4. Kagwanja P, 'Power and peace: South Africa and the refurbishing of Africa's multilateral capacity for peacemaking', Journal of Contemporary African Studies, 24.2, 2006, p. 169.

5. United Nations Development Programme, Human Development Report. The Rise of the South: Human Progress in a Diverse World. New York, 2013.

6. Fioramonti L, 'Is the EU a "better" global player: An analysis of emerging powers' perceptions', in Renard T \& S Biscop (eds) The European Union and Emerging Powers in the 21st Century. Farnham: Ashgate, 2012.

7. Habib A, 'South Africa's foreign policy: Hegemonic aspirations, neoliberal orientations and global transformation', South African Journal of International Affairs, 16.2, 2009, p. 151.

8. Masters L, 'Building bridges? South African foreign policy and trilateral development cooperation', South African Journal of International Affairs, 21.2, 2014, pp. 177-91.

9. Keukeleire $S \&$ T Delreux, 'Competing structural powers and challenges for the EU's structural foreign policy', Global Affairs, 1.1, 2015.

10. Fioramonti L, European Union Democracy Aid: Supporting Civil Society in Post-Apartheid South Africa. London: Routledge, 2010.

11. European Commission DG Trade, European Union, Trade in Goods with South Africa. Brussels, 2013.

12. European Commission DG Trade, South Africa Trade, http://ec.europa.eu/trade/policy/ countries-and-regions/countries/south-africa/ (accessed 15 February 2015).

13. Olivier G, 'The European Union and South Africa: Towards a strategic partnership?', South African Journal of International Affairs, 13.2, 2006, p. 178.

14. Habib A, 'South Africa's foreign policy: Hegemonic aspirations, neoliberal orientations and global transformation', South African Journal of International Affairs 16.2, 2009, p. 144.

15. European Union, Cooperation between the European Union and South Africa: Joint Country Strategy Paper 2007-2013, Brussels, 2007, p. 3, http://eeas.europa.eu/south_ africa/csp/07_13_en.pdf (accessed 15 February 2015). 
16. Department of International Relations and Cooperation, Building a Better World: The Diplomacy of Ubuntu. White Paper of South Africa's Foreign Policy. Pretoria: DIRCO, 2011, p. 31.

17. Stevens C, 'Economic partnership agreements and Africa: Losing friends and failing to influence', in Carbone M (ed.) The European Union in Africa. Manchester: Manchester University Press, 2013, p. 179.

18. Negotiations were completed in July 2014. As of September 2015 the agreement is still in the process of preparation for ratification. See European Commission, 'Overview of EPA negotiations', 2015, http://trade.ec.europa.eu/doclib/docs/2009/september/tradoc_144912. pdf

19. European Commission, Cooperation between the European Union and South Africa - Joint Country Strategy Paper 2007-2013.

20. Zondi S, 'South Africa-EU strategic partnership in the context of a changing NorthSouth power dynamics', ECDPM GREAT Insights 2.6, 2013, p. 3.

21. Ibid.

22. Interview. EU Official, Delegation of the EU, Pretoria, South Africa, 6 May, 2015.

23. Ibid.

24. Alden C \& G Le Pere, 'South Africa's Post-apartheid foreign policy: From reconciliation to ambiguity?' Review of African Political Economy, 31.100, 2004, p. 293.

25. Department of International Relations and Cooperation, Building a Better World: The Diplomacy of Ubuntu. White Paper of South Africa's Foreign Policy. Pretoria: DIRCO, 2011, p. 31.

26. Fioramonti L \& G Olivier, 'Altruism or self-interest? An exploratory study of the EU's external image in South Africa', European Foreign Affairs Review, 12.3, 2007.

27. Alden C \& M Schoeman, 'South Africa in the company of giants: The search for leadership in a transforming global order', International Affairs, 89.1, 2013, p. 114.

28. Moore C, 'Where to from here', LSE Ideas (2012), http://blogs.lse.ac.uk/ideas/2012/10/ where-to-from-here-for-south-africas-foreign-policy/

29. Marthoz JP, 'The challenges and ambiguities of South Africa's foreign policy', NOREF Report, Norwegian Peacebuilding Resource Centre, 2012.

30. Alden C \& G Le Pere, 'South Africa in Africa: Bound to lead?', Politikon, 36.1, 2009, p. 145.

31. Barber J, 'The New South Africa's foreign policy: Principles and practice', International Affairs, 81.5, 2005, p. 1083.

32. Kagwanja P, 'Power and peace: South Africa and the refurbishing of Africa's multilateral capacity for peacemaking', Journal of Contemporary African Studies, 24.2, 2006, p. 162.

33. Barber J, 'The New South Africa's foreign policy: Principles and practice', International Affairs, 81.5, 2005, p. 1083.

34. Kagwanja P, 'Power and peace: South Africa and the refurbishing of Africa's multilateral capacity for peacemaking', Journal of Contemporary African Studies, 24.2, 2006, p. 159.

35. Alden C \& G Le Pere, 'South Africa in Africa: Bound to lead?', Politikon, 36.1, 2009, p. 145.

36. Barber J, 'The new South Africa's foreign policy: Principles and practice', International Affairs, 81.5, 2005, p. 1083.

37. Sidiropoulos E, 'South African foreign policy in the post-Mbeki period', South African Journal of International Affairs, 15.2, 2008, p. 109.

38. Vale P \& S Maseko, 'South Africa and the African Renaissance', International Affairs, 74.2, 1998, p. 271.

39. Alden C \& G Le Pere, 'South Africa's post-apartheid foreign policy: From reconciliation to ambiguity?' Review of African Political Economy, 31.100, 2004, p. 292.

40. Kagwanja P, 'Power and peace: South Africa and the refurbishing of Africa's multilateral capacity for peacemaking', Journal of Contemporary African Studies, 24.2, 2006, p. 168.

41. Ibid.

42. Nathan L, 'African solutions to African problems', WeltTrends: Zeitschrift für internationale Politik, 92.21, September/Oktober 2013, p. 48.

43. Nathan L, 'Consistency and inconsistencies in South Africa foreign policy', International Affairs, 81.2, 2005, p. 366.

44. Ibid., 367 . 
45. Interview. EU Official, Delegation of the EU, Pretoria, South Africa, 25 August 2014.

46. Landsberg C, 'The foreign policy of the Zuma Government: Pursuing the "national interest"?', South African Journal of International Affairs, 17.3, 2010, p. 174.

47. Fabricius P, 'South Africa arms itself for battle with the ICC', ISS Weekly, 8 October 2015.

48. Alden C \& G Le Pere, 'South Africa in Africa: Bound to lead?', Politikon, 36.1, 2009, p. 161.

49. Bond, P, 'The ANC's "left turn" and South African sub-imperialism', Review of African Political Economy, 31.102, 2004, pp. 599-616.

50. Adesina J, 'NEPAD and the challenge of Africa's development: Towards the political economy of a discourse', African Journal of International Affairs, 4.1-2, 2001, p. 2.

51. Sidiropoulos E, 'South African foreign policy in the post-Mbeki period', South African Journal of International Affairs, 15.2, 2008, p. 115.

52. Marrian N, 'Tension rises as election for AU top post nears,' Business Day, 8 August 2012, http://www.bdlive.co.za/articles/2012/07/13/tension-rises-as-election-for-au-top-postnears;jsessionid=9ED962DD050D448F6FC5234156AEED01. present2.bdfm (accessed 15 February 2015).

53. Tywuschik V \& A Sherriff, 'Beyond structures? Reflections on the Implementation of the joint Africa-EU strategy', ECDPM Discussion Paper 87, 2009.

54. Kotsopoulos J \& L Fioramonti, 'South Africa's inconsistent role in bolstering EU-Africa relations', EUSA Review, Fall 2014, p. 10.

55. Building a Better World: The Diplomacy of Ubuntu. White Paper of South Africa's Foreign Policy, 31.

56. Council of the European Union, Fifth European Union-South Africa Summit - Joint Communiqué, http://europa.eu/rapid/press-release_PRES-12-384_en.htm (accessed 15 February 2015).

57. The 2014-2016 Action Programme for the African Peace Facility assigned EUR750 million for 'Africa-led' peace and security initiatives, including APSA, https://ec.europa. eu/europeaid/regions/africa/continental-cooperation/african-peace-facility_en

58. Fioramonti L, 'The European Union promoting development in Africa: The economic partnership agreements as a case of aggressive multilateralism', in Bouchard C, J Peterson \& N Tocci (eds) Multilateralism in the 21st century: Europe's quest for effectiveness. London: Routledge, 2013.

59. Grant C, 'Southern Africa and the European Union: The TDCA and SADC EPA', TRALAC Trade Brief, 1, 2006.

60. Cronin D, 'EPA signed "under duress", says South Africa', Inter Press Service, 21 December 2007, http://ipsnews.net/news.asp?idnews=40567 (accessed 15 January 2015).

61. Ibid.

62. Kornegay F \& G Olivier G, 'The European Union and Africa's regional economic communities: Asymmetrical versus developmental multilateralism', MERCURY Working Paper, April 2011, pp. 7-8.

63. Draper P, 'Africa-EU trade relations: Round number two!', VOX: Research-based Policy Analysis, 29 January 2012, http://www.voxeu.org/index.php?q=node/896 (accessed 15 February 2015).

64. African Union, Short Background Brief on Economic Partnership Agreements, AU Conference of Ministers of Trade, 15-16 January, 2007, hubrural.org/IMG/pdflau_trade_min_backgrd_0107.pdf (accessed 15 February 2015).

65. Van der Merwe C, 'Zuma urges SACU to tackle EPA negotiations as a united front,' Engineering News South Africa, 23 April 2010, http://www.bilaterals.org/spip.php? article17195andlang=en (accessed 15 February 2015).

66. European Parliament, Written Declaration on Science Capacity Building in Africa: Promoting European-African Radio Astronomy Partnerships (0045/2011), Brussels, 2011.

67. Zuma J, 'Closing address by Jacob Zuma to the conference on the European Union's Innovation for Poverty Alleviation programme with South Africa', African National Congress, 2012.

68. Vidal J \& F Harvey, 'India dampens Europe's hopes of a new climate change agreement', The Guardian, 6 December 2011; Qi, Xinran, 'The rise of BASIC in UN climate change negotiations', South African Journal of International Affairs, 18.3, December 2011, pp. 295-318. 
69. Focus group discussion with EU senior officials held in Pretoria at the EU Delegation to South Africa on 25 August 2014.

70. Interview. EU Official, Delegation of the EU, Pretoria, South Africa, 6 May 2015.

71. Feder JL, 'LGBT rights resolution passes United Nations Human Rights Council in lopsided vote', Buzzfeed, 2014, http://www.buzzfeed.com/lesterfeder/lgbt-rights-resolutionpasses-united-nations-human-rights-co\#ijt7un

72. Interview, EU Official, Delegation of the EU, Pretoria, South Africa, 6 May 2015.

73. Reid G, 'South Africa's worrying prevarication on LGBT rights', Human Rights Watch, 2014.

74. Focus group discussion with EU senior officials held in Pretoria at the EU Delegation to South Africa on 25 August 2014.

75. Habib A, 'South Africa's foreign policy under Zuma', 2011, http://www.thebrokeronline. $\mathrm{eu} / \mathrm{Blogs} /$ Emerged-powers-in-the-21st-century/South-Africa-s-foreign-policy-underZuma

76. Alden C \& G Le Pere, 'South Africa's post-apartheid foreign policy: From reconciliation to ambiguity?', Review of African Political Economy, 31.100, 2004, p. 290.

77. Zuma J, 'Closing address by Jacob Zuma to the conference on the European Union's Innovation for Poverty Alleviation programme with South Africa'.

78. 'Zuma blames European bombing for Libyan refugee crisis', Times Live, 15 September 2015, http://www.timeslive.co.za/politics/2015/09/15/Zuma-blames-European-bombingfor-Libyan-refugee-crisis (accessed 17 September 2015).

79. Brosig M, 'Interregionalism at a crossroads: African-European crisis management in Libya - a case of organized inaction?', Journal of International Organizations Studies, $4.2,2013$, pp. $57-74$.

80. Grant C, 'Southern Africa and the European Union: The TDCA and SADC EPA', TRALAC Trade Brief, 1, 2006.

81. Habib A, 'South Africa's foreign policy: Hegemonic aspirations, neoliberal orientations and global transformation', South African Journal of International Affairs, 16.2, 2009, p. 151.

82. Barber J, 'The New South Africa's foreign policy: Principles and practice', International Affairs, 81.5, 2005, p. 1083.

83. Department of International Relations and Cooperation, Building a Better World: The Diplomacy of Ubuntu. White Paper of South Africa's Foreign Policy. Pretoria: DIRCO, 2011, p. 32.

84. Kotsopoulos J \& L Fioramonti, 'South Africa's inconsistent role in bolstering EU-Africa Relations', EUSA Review, Fall 2014, p. 11. 